TITLE:

\title{
Ingestion and excretion of nitrogen by larvae of a cabbage armyworm: the effects of fertilizer application
}

$\operatorname{AUTHOR}(S)$ :

Kagata, Hideki; Ohgushi, Takayuki

\section{CITATION:}

Kagata, Hideki ...[et al]. Ingestion and excretion of nitrogen by larvae of a cabbage armyworm: the effects of fertilizer application. Agricultural and Forest Entomology 2011, 13(2): 143-148

\section{ISSUE DATE:}

2011-05

URL:

http://hdl.handle.net/2433/197186

\section{RIGHT:}

This is the peer reviewed version of the following article: Kagata, H. and Ohgushi, T. (2011), Ingestion and excretion of nitrogen by larvae of a cabbage armyworm: the effects of fertilizer application. Agricultural and Forest Entomology, 13: 143-148, which has been published in final form at http://dx.doi.org/10.1111/j.1461-9563.2010.00502.x; This is not the published version. Please cite only the published version.; この論文は出版社版でありません。引用の際には出版社版

をご確認じ利用ください。 


\section{Ingestion and excretion of nitrogen by larvae of a cabbage}

\section{armyworm: the effects of fertilizer application}

Hideki Kagata and Takayuki Ohgushi

Center for Ecological Research, Kyoto University: 509-3, Hirano 2-chome, Otsu, Shiga

520-2113, Japan

Correspondence: Hideki Kagata. Tel: +81 77549 8214; Fax: +81 77549 8201; e-mail:

kagata@ecology.kyoto-u.ac.jp

Running title: Nitrogen excretion by Maestro brassicae larvae 


\section{Abstract}

1 Insect frass has significant impacts on decomposition and nitrogen (N) dynamics in soil. Although the frass contained $\mathrm{N}$ with various forms that may differently influence $\mathrm{N}$ dynamics in the decomposition process, it is poorly understood how the $\mathrm{N}$ form in the insect frass is influenced by host plant quality.

2 This study examined the effects of application of fertilizer on leaf quality of

Brassica rapa L. var. perviridis Bailey (Brassicaceae), and on the consumption, frass excretion, and frass quality of its insect pest, Mamestra brassicae (L.) (Lepidoptera: Noctuidae), with a particular focus on dynamics of inorganic $\mathrm{N}$.

3 Brassica rapa increased total $\mathrm{N}$ concentration, and accumulated inorganic $\mathrm{N}$ (i.e.,

$25 \mathrm{NO}_{3}{ }^{-}-\mathrm{N}$ and $\mathrm{NH}_{4}{ }^{+}-\mathrm{N}$ ) into the leaves in response to application of fertilizer.

4 While amount of leaf consumption and excreted frass of M. brassicae was not affected by the levels of fertilization, frass quality was evidently influenced by host plant quality altered by fertilization. The frass contained high levels of total $\mathrm{N}$, $\mathrm{NO}_{3}{ }^{-}-\mathrm{N}$, and $\mathrm{NH}_{4}{ }^{+}-\mathrm{N}$ under high fertilization. In particular, the larvae excreted much 
30 more $\mathrm{NH}_{4}{ }^{+}-\mathrm{N}$ than that ingested. We discussed on the relationship between host plant

quality and insect frass quality, and suggested that the potential effects of such frass

characteristics altered by the host plants on decomposition and nutrient dynamics.

Keywords Ammonium, frass, nitrate, nitrogen metabolism, nutritional ecology,

35 plant-insect interaction. 


\section{Introduction}

There is increasing evidence that the consumption of living foliage by herbivorous

insects has significant impacts on ecosystem processes (Belovsky \& Slade, 2000;

40 Hunter, 2001; Weisser \& Siemann, 2004). Deposition of insect excrements (i.e., frass

and honeydew) is one of the pathways affecting decomposition process and nutrient

dynamics in soil (Hunter, 2001; Weisser \& Siemann, 2004). Insect frass contains more

labile carbon than does leaf litter (Lovett et al., 2002). Therefore, it can stimulate

microbial growth in the soil (Frost \& Hunter, 2004), which subsequently affects

45 nitrogen (N) mineralization or immobilization (Lovett \& Ruesink, 1995; Frost \& Hunter,

2007). Thus, insect herbivores can play important role influencing $\mathrm{N}$ dynamics in soil,

i.e., transforming organic $\mathrm{N}$ into inorganic $\mathrm{N}$ and vice versa, through frass

decomposition process.

On the other hand, frass of herbivorous insects contains $\mathrm{N}$ with various forms

50 (Cochran, 1985; O’Donnell, 2008). Proteins and amino acids are detected in insect frass,

and they are regarded as excretion of unabsorbed, excessive amounts of proteins and 
amino acids derived from the diet (Cochran, 1985). Uric acid (and related compounds

such as allantoin and allantoic acid) is known as principal end-products of $\mathrm{N}$

metabolism in terrestrial insects (Craig, 1960; Cochran, 1985). Nitrogenous excretion

by uric acid will be an evolutionary consequence for water conservation in terrestrial

animals; uric acid requires less water than ammonia and urea for excretion (Wright, 1995). Nevertheless, ammonia is commonly detected in the frass of terrestrial insects (Cochran, 1985; Lovett \& Ruesink, 1995; Kuzhivelil \& Mohamed, 1998; Lovett et al., 2002), and it was ca. 9-27 \% of total N in the frass (Lovett \& Ruesink, 1995; Kuzhivelil

60 \& Mohamed, 1998). This indicates that plant organic N (proteins and amino acids)

ingested by herbivorous insects is transformed to some extent into inorganic form during $\mathrm{N}$ metabolism of insects, prior to the decomposition of frass deposited to the soil. Hence, understanding the effects of insect herbivores on $\mathrm{N}$ dynamics (mineralization and immobilization) through frass excretion will be incomplete without knowledge on

$65 \mathrm{~N}$ form in the frass. In addition, composition of such $\mathrm{N}$ compounds in the frass of herbivorous insects is expected to vary as their diet quality, because $\mathrm{N}$ use efficiency of herbivorous insects is altered by amount of $\mathrm{N}$ in the host plants (Slansky \& Feeny, 1977; 
Simpson \& Raubenheimer, 2001; Giertych et al., 2005). However, it is poorly

understood the effects of plant quality on $\mathrm{N}$ form in the frass of herbivorous insects,

which would potentially influence decomposition process and nutrient dynamics in soil.

The present study investigated the relationship between $\mathrm{N}$ status of the host plant and frass of the herbivorous insect, with a particular focus on total $\mathrm{N}$ and inorganic $\mathrm{N}$ concentration, in various fertilization levels. We examined the effects of application of fertilizer on leaf quality of a vegetable crop, Brassica rapa L. var. perviridis Bailey

75 (Brassicaceae), and on the consumption, frass excretion, and frass quality of its insect pest, cabbage armyworm, Mamestra brassicae (L.) (Lepidoptera: Noctuidae).

\section{Materials and Methods}

\section{Culture of $B$. rapa}

Brassica rapa plants (Rakuten, Takii Syubyo Co. Ltd., Kyoto, Japan) were individually grown in 500ml pots using nutrient-rich compost (Tanemaki-baido, Takii Syubyo Co. Ltd., Kyoto, Japan) as growth medium in a glass-shield greenhouse at $25^{\circ} \mathrm{C}$ under 
natural light conditions. After seeding, plants were watered daily. The plants were fertilized with liquid fertilizer (HYPONeX; N:P:K = 6:10:5, HYPONeX JAPAN Co.

Ltd., Osaka, Japan). We used NPK fertilizer instead of N fertilizer, because our aim is to understand the effects of nitrogen addition on quality of host plant and insect frass without limitation of other nutrient elements, such as phosphorus. It is known that absorption and utilization of one nutrient element in plants and insects are affected by

90 amount of other nutrient elements (Sterner \& Elser, 2002; Huberty \& Denno, 2006). As our experimental treatments include relatively high fertilization levels (see below), only $\mathrm{N}$ fertilization may result in insufficient supply of other nutrient elements. Four fertilizer levels were established: (1) high: 30-fold dilution, (2) medium: 100-fold dilution, (3) low: 300-fold dilution, (4) none (control): water only. This fertilizer is

95 usually used with 500-fold dilution for culture of vegetables. Two weeks after seeding, when the plants reached the four-true-leaf stage, $50 \mathrm{ml}$ of fertilizer solution or $50 \mathrm{ml}$ of water were added to individual pots at one-week intervals. Plants were grown for 4 weeks, and then used for the analyses of leaf quality and feeding trials described below. 


\section{Leaf quality of $B$. rapa}

Leaf $\mathrm{N}$ analyses were conducted for randomly selected 12 individuals of $B$. rapa for

each treatment. Two mature leaves without petiole were collected from each individual.

They were oven dried at $60^{\circ} \mathrm{C}$ for $72 \mathrm{~h}$ and ground to a fine powder. Leaf total $\mathrm{N}$ concentration was determined using an elemental analyzer (JM 1000CN, J-Science Co.

105 Ltd., Kyoto, Japan). Leaf nitrate-N $\left(\mathrm{NO}_{3}{ }^{-}-\mathrm{N}\right)$ and ammonium-N $\left(\mathrm{NH}_{4}{ }^{+}-\mathrm{N}\right)$ were extracted using $1.5 \mathrm{~mol} / \mathrm{l} \mathrm{KCl}$ and concentrations were determined using a continuous flow analyzer (Integral Futura, Alliance Instruments, Frépillon, France).

\section{Consumption, frass excretion, and frass quality of $M$. brassicae}

110 Mamestra brassicae was from a laboratory population at the Center for Ecological

Research, Kyoto University. Egg clusters were placed individually in petri dishes $(9 \mathrm{~cm}$ in diameter) in an environmental chamber at $25^{\circ} \mathrm{C}$ with a $16 \mathrm{~L} 8 \mathrm{D}$ light cycle. The hatched larvae were reared together until the third instar, and thereafter five larvae were reared per petri dish. Prior to the feeding trials, larvae were provided with artificial diet

115 (Insecta LFS, Nihon Nosan Kogyo Co. Ltd., Yokohama, Japan). Randomly selected 
sixth (last) instar larvae were used for the feeding trials. It is known that most (60-80\%)

of the food consumption of immature stage occurs during the last instar larvae in Lepidoptera (Furuno, 1964; Scriber \& Slansky, 1981). Hence, consumption and frass excretion during this larval period would be important on $\mathrm{N}$ dynamics from host plants

120 to insect frass. The larvae were kept for $12 \mathrm{~h}$ without diet before the feeding trials to excrete the frass of artificial diet origin. Each larva was placed in a petri dish $(14.5 \mathrm{~cm}$ in diameter) with one or two mature, petiole-removed leaves of B. rapa from one each of the four fertilization treatments described above. The B. rapa leaves and $M$. brassicae larvae were weighed prior to the feeding trials. The larvae were reared for $48 \mathrm{~h}$ in the

125 environmental chamber, and then B. rapa leaves were removed and the larvae were kept for $12 \mathrm{~h}$ without diet to excrete the frass in the gut. Thereafter, larval frass excreted during the feeding trial was collected. Brassica rapa leaves, and frass were oven dried at $60^{\circ} \mathrm{C}$ for $72 \mathrm{~h}$ to determine dry weight. Twenty replicates were conducted for each treatment. Consumed leaf mass was determined as the difference in leaf dry mass

130 between the start and the end of the experiment. Dry mass of B. rapa leaves and $M$. brassicae larvae at the start of the experiment were estimated from their water contents, 
which were measured using extra samples. The water contents were determined from the difference between fresh and dry mass which was measured after oven dried at $60^{\circ} \mathrm{C}$ for $72 \mathrm{~h}$ ( $\mathrm{n}=12$ for B. rapa leaves for each treatment, and $\mathrm{n}=15$ for $M$. brassicae

135 larvae).

For $\mathrm{N}$ analyses, frass was ground to a fine powder. Total and inorganic $\mathrm{N}$ in frass were determined by the same methods as for the analyses for B. rapa leaf N. Frass from 10 replicates for each treatment was used for total $\mathrm{N}$ analysis and that from another 10 replicates was used for inorganic $\mathrm{N}$ (i.e. $\mathrm{NO}_{3}{ }^{-}-\mathrm{N}$ and $\mathrm{NH}_{4}{ }^{+}-\mathrm{N}$ ) analysis, because one

140 frass sample did not have sufficient mass to measure both total and inorganic N.

\section{Statistical analysis}

All comparisons were tested by one-way ANOVA with the Tukey-Kramer HSD test $(\mathrm{P}<0.05)$. Percentage data were arcsine-square root transformed prior to analysis. The excretion efficiency for consumed biomass, total $\mathrm{N}, \mathrm{NO}_{3}{ }^{-}-\mathrm{N}$, and $\mathrm{NH}_{4}{ }^{+}-\mathrm{N}$ was shown by regression plots with treatment averages, and the relationships between ingested and excreted mass were tested by regression analysis. All analyses were conducted using 
JMP version 6 (SAS Institute Japan, Tokyo, Japan).

\section{Results}

\section{Leaf quality of $B$. rapa}

The water content of $B$. rapa leaves was not affected by the fertilization level (ANOVA;

$\left.F_{3,47}=1.31, P=0.28\right)$, and the mean percentage of leaf water was $87.4 \pm 0.3 \%(\mathrm{SE})$.

155 Fertilization significantly affected total $\mathrm{N}, \mathrm{NO}_{3}{ }^{-}-\mathrm{N}$, and $\mathrm{NH}_{4}{ }^{+}-\mathrm{N}$ concentration in leaves

(ANOVA: $F_{3,47}=19.3, P<0.0001$ for total $\mathrm{N} ; F_{3,47}=13.3, P<0.0001$ for $\mathrm{NO}_{3}{ }^{-}-\mathrm{N} ; F_{3,47}$

$=16.6, P<0.0001$ for $\mathrm{NH}_{4}{ }^{+}-\mathrm{N}$; Fig. 1a-c). Total $\mathrm{N}$ concentration was highest in the high

fertilization treatment, followed by the medium fertilization treatment. Plants in the low

and no fertilization treatments had the lowest percentages of total $\mathrm{N}$, and there was no

160 significant difference between these two treatments (Fig. 1a). $\mathrm{NO}_{3}{ }^{-}-\mathrm{N}$ concentration was

highest in the high fertilization treatment followed by the medium fertilization treatment.

$\mathrm{NO}_{3}{ }^{-}-\mathrm{N}$ concentration did not differ between the low and no fertilization treatments (Fig.

1b). Plants in the high fertilization treatment had a significantly higher percentage of 
$\mathrm{NH}_{4}{ }^{+}-\mathrm{N}$, compared to other three treatments. $\mathrm{NH}_{4}{ }^{+}-\mathrm{N}$ concentration did not significantly

differ among the medium, low, and no fertilization treatments (Fig. 1c).

\section{Consumption, excretion, and frass quality of $M$. brassicae}

The larval dry mass at the start of the experiment did not differ significantly among the four treatments (ANOVA: $F_{3,79}=1.05, P=0.38$, overall mean $\pm \mathrm{SE}=86.1 \pm 1.0 \mathrm{mg}$ ).

170 The larvae consumed at most $70 \%$ of biomass of the leaves provided for the feeding trials, and this indicates that food shortage did not occur during the experiment. The dry mass of $B$. rapa leaves consumed by $M$. brassicae did not significantly differ among the treatments (ANOVA: $F_{3,79}=0.79, P=0.50$; Fig. 2a). Amount of frass excreted by $M$. brassicae did not differ among the treatments (ANOVA: $F_{3,79}=1.85, P=0.14$; Fig. $2 \mathrm{~b}$ ).

175 There was no relationship between ingested and excreted mass (Fig. 2c), and on average, $50.2 \pm 3.4 \%$ of ingested food was excreted as frass.

Total $\mathrm{N}$ concentration in frass differed significantly among the treatments $\left(F_{3.39}=\right.$ 14.2, $P<0.0001$; Fig. 3a). Frass excreted by the larvae in the high fertilization treatment had the highest level of $\mathrm{N}$, followed by that from larvae in the medium 
180 fertilization treatment. Frass $\mathrm{N}$ in the no fertilization treatment was the lowest. $\mathrm{NO}_{3}{ }^{-}-\mathrm{N}$

and $\mathrm{NH}_{4}{ }^{+}-\mathrm{N}$ concentrations in frass were also affected by the fertilization treatment

(ANOVA: $F_{3,39}=6.16, P=0.0017$ for $\mathrm{NO}_{3}{ }^{-}-\mathrm{N} ; F_{3.39}=10.2 . P<0.0001$ for $\mathrm{NH}_{4}{ }^{+}-\mathrm{N}$; Fig.

$3 \mathrm{~b}$ and c). Frass in the high fertilization treatment had the highest levels of $\mathrm{NO}_{3}{ }^{-}-\mathrm{N}$ and

$\mathrm{NH}_{4}{ }^{+}-\mathrm{N}$, and frass in the low and no fertilization treatments had the lowest levels.

them (Fig. 4a and b). Overall, $54.6 \pm 3.8 \%$ and $60.4 \pm 4.4 \%$ of the ingested $\mathrm{N}$ and

$\mathrm{NO}_{3}{ }^{-}-\mathrm{N}$ was excreted as frass, respectively. While there was no significant relationship

between ingested and excreted $\mathrm{NH}_{4}{ }^{+}-\mathrm{N}$, the larvae excreted more $\mathrm{NH}_{4}{ }^{+}-\mathrm{N}$ than ingested

one (Fig. 4c). On the other hand, there was significant relationship between ingested $\mathrm{N}$

190 and excreted $\mathrm{NH}_{4}{ }^{+}-\mathrm{N}$, and excreted $\mathrm{NH}_{4}{ }^{+}-\mathrm{N}$ increased in response to ingested $\mathrm{N}$ (Fig.

$4 d)$.

\section{Discussion}




\section{Accumulation of inorganic $\mathbf{N}$ in $B$. rapa leaves}

The present study clearly showed that $B$. rapa not only increased total $\mathrm{N}$, but also accumulated inorganic $\mathrm{N}$ (i.e., $\mathrm{NO}_{3}{ }^{-}-\mathrm{N}$ and $\mathrm{NH}_{4}{ }^{+}-\mathrm{N}$ ) into the leaves in response to the application of fertilizer. The process of $\mathrm{N}$ assimilation in plants has been well documented, and summarized by several authors (e.g. Huppe \& Turpin, 1994; Crawford, 1995). In brief, plants can use both nitrate and ammonia as $\mathrm{N}$ resource. While ammonia is directly utilized for synthesis of amino acids, nitrate is first reduced to nitrite by nitrate reductase. Nitrite is then reduced to ammonia by nitrite reductase. Thereafter, ammonia is fixed into glutamate to produce glutamine by the action of glutamine synthetase. When the plants were provided with excess nitrate, the nitrate is stored in

205 vacuoles by regulation of nitrate reduction process (Martinoia et al., 1981). The high level of accumulation of nitrate in B. rapa leaves observed in the high fertilization treatment indicates that the fertilization level in this study was excessive beyond the level of nitrate that B. rapa is able to assimilate. Yorifuji et al. (2005) reported that $B$. rapa plants in Japanese markets have on average 4,060 ppm nitrate ( $\mathrm{n}=197$, range:

210 128-9,460 ppm) in fresh weight. This indicates that many of B. rapa in Japanese 
markets contained higher level of nitrate than the maximum level in vegetables $(4,500$ ppm), which was established by European Commission Regulation (European Commission, 2005). However, B. rapa having high nitrate is being circulated because there is no regulation about nitrate in vegetables in Japan. When the $\mathrm{NO}_{3}{ }^{-}-\mathrm{N}$ concentration observed in the present study was converted to the nitrate concentration in fresh weight, the highest concentration was 5,337 ppm for the leaves in the high fertilization treatment. This value is within a range of the concentration of $B$. rapa in Japanese markets. Hence, the fertilization level in the present study appears to be within the range of the fertilization level used in B. rapa culture in Japan. In addition to the 220 nitrate accumulation, our results showed that ammonium was also accumulated in the leaves under high fertilization, although the concentration was lower than that of nitrate. Because the fertilizer used in the present study contained both nitrate and ammonium, the fertilization level in this study would be also excessive beyond the levels of ammonium that $B$. rapa is able to synthesize glutamine. 


\section{Consumption, excretion, and frass quality of $M$. brassicae}

While a number of studies have dealt with the effects of host plant quality on feeding behaviour, nutrient utilization, and growth of herbivorous insects (e.g. Slansky \& Feeny, 1977; Fischer \& Fiedler, 2000; Simpson \& Raubenheimer, 2001; Giertych et al., 2005;

230 Chen et al., 2007; Hwang et al., 2008; Staley et al., 2009), the effects of host plant quality on the frass quality, in particular inorganic N, have received less attention. However, $\mathrm{N}$ forms in the frass would be important to understand the roles of insect herbivores on $\mathrm{N}$ dynamics at ecosystem level through the frass excretion.

The present study showed that the B. rapa leaf quality altered by fertilization did

235 not affect the amount of leaf consumption and excreted frass of $M$. brassicae larvae.

One reason why the plant quality did not affect the feeding and excretion behaviour of the insect would be a short time period for the feeding trials. While M. brassicae larva takes approximately one month until pupation at our rearing condition $(\mathrm{H}$. Kagata, personal observation), the feeding trial was conducted only for $48 \mathrm{~h}$ with last instar

240 larvae. Therefore, our experimental design would not be sufficient to detect the effects of host plant quality on such behaviour. 
On the other hand, the present study clearly demonstrated that quality of $M$.

brassicae frass was influenced by host plant quality, and that the frass had high levels of total $\mathrm{N}, \mathrm{NO}_{3}{ }^{-}-\mathrm{N}$, and $\mathrm{NH}_{4}{ }^{+}-\mathrm{N}$ as a result of the altered quality of the host plants under

245 high fertilization. Inorganic $\mathrm{N}$ in the frass mostly comprised ammonium form, and it was from $9 \%$ (in no fertilization) to $27 \%$ (in high fertilization) of total $\mathrm{N}$ in the frass (see Fig. 3). The rest would be organic $\mathrm{N}$ such as amino acids and proteins, which were unabsorbed in the insect gut, and uric acid and related compounds as end-products of $\mathrm{N}$ metabolism (Cochran, 1985; Lovett et al., 2002). $\mathrm{NO}_{3}{ }^{-}-\mathrm{N}$ in the frass is likely to be diet origin, rather than $\mathrm{N}$ metabolism product of the herbivorous insect, because the amount of excreted $\mathrm{NO}_{3}{ }^{-}-\mathrm{N}$ was less than that ingested, and it was well explained by amount of ingested $\mathrm{NO}_{3}{ }^{-}-\mathrm{N}$. In addition, there is no report, in our knowledge, that nitrate was produced as subsequence of $\mathrm{N}$ metabolism in herbivorous insects. In contrast, $\mathrm{NH}_{4}{ }^{+}-\mathrm{N}$ in the frass would originate from $\mathrm{N}$ metabolism by the insect, rather than diet origin.

255 The amount of excreted $\mathrm{NH}_{4}{ }^{+}-\mathrm{N}$ was as from 5- to 17 -fold greater as that ingested (see Fig. 4c), and amount of excreted $\mathrm{NH}_{4}{ }^{+}-\mathrm{N}$ as the frass was explained by amount of ingested $\mathrm{N}$ rather than by ingested $\mathrm{NH}_{4}{ }^{+}-\mathrm{N}$ (see Fig. 4c and d). These indicate that high 
levels of $\mathrm{N}$ in the host plants would promote the $\mathrm{N}$ metabolism, and subsequently

accelerate ammonium excretion of the herbivorous insect.

Thus, we concluded that $\mathrm{N}$ in the host plant largely influenced insect frass quality, especially ammonium concentration, by enhancing the metabolic process in the herbivorous insect. Such frass characteristics altered by the host plants would differently influence decomposition and nutrient dynamics in soil. In general, $\mathrm{N}$ is one of the factors that control decomposition rate, and the substrates with high $\mathrm{N}$ are more rapidly

265 decomposed (Hättenschwiler et al., 2005). Nitrate and ammonium in the frass may also have impacts on nutrient dynamics, because they are the form that plants can directly utilize without time lag necessary for $\mathrm{N}$ mineralization in usual decomposition process. In addition, it is known that the frass quality differed depending on insect species, even when they fed on same host plant (Madritch et al., 2007). Therefore, effects of insect frass on decomposition and nutrient dynamics may be more variable than we expected from the frass decomposition experiments using a single plant-insect interaction (e.g. Lovett \& Ruesink, 1995; Christenson et al., 2002; Frost \& Hunter, 2004, 2007). Further studies to clarify the effects of insect frass quality on the decomposition and nutrient 
dynamics will contribute to generate a general picture of how herbivores can influence

ecosystem processes.

\section{Acknowledgements}

We thank T. Matoh and M. Uefune for valuable information on B. rapa culture, and A.

280 Fuchikawa for help in maintaining the M. brassicae populations. We also thank S. Kita

for help in measuring nitrate and ammonium concentrations, and E. Nakajima for

English proofreading of our manuscript. This study was supported by a JSPS Research

Fellowship for Young Scientists, Grant-in-Aid for Scientific Research (B-20370010),

and Kyoto University Global COE Program (A06). 


\section{References}

Belovsky, G.E. \& Slade, J.B. (2000) Insect herbivory accelerates nutrient cycling and increases plant production. Proceedings of the National Academy of Sciences of the United States of America, 97, 14414-14417.

Chen, Y., Ruberson, J.R., \& Olson, D.M. (2007) Nitrogen fertilization rate affects feeding, larval performance, and oviposition preference of the beet armyworm, Spodoptera exigua, on cotton. Entomologia Experimentalis et Applicata, 126, 244-255.

Christenson, L.M., Lovett, G.M., Mitchell, M.J., \& Groffman, P.M. (2002) The fate of nitrogen in gypsy moth frass deposited to an oak forest floor. Oecologia, 131, 444-452.

Cochran, D.G. (1985) Nitrogen excretion in cockroaches. Annual Review of Entomology, 30, 29-49.

Craig, R. (1960) The physiology of excretion in the insect. Annual Review of Entomology, 5, 53-68.

300 Crawford, N.M. (1995) Nitrate: nutrient and signal for plant growth. The plant Cell, 7, 859-868. European Commission (2005) Commission Regulation (EC) No 1822/2005 of 8 November 
2005 amending Regulation (EC) No 466/2001 as regards nitrate in certain vegetables.

Official Journal of the European Union, 48, 11-13.

Fischer, K. \& Fiedler, K. (2000) Response of the copper butterfly Lycaena tityrus to increased leaf nitrogen in natural food plants. Oecologia, 124, 235-241.

Frost, C.J. \& Hunter, M.D. (2004) Insect canopy herbivory and frass deposition affect soil nutrient dynamics and export in oak mesocosms. Ecology, 85, 3335-3347.

Frost, C.J. \& Hunter, M.D. (2007) Recycling of nitrogen in herbivore feces: plant recovery, herbivore assimilation, soil retention, and leaching losses. Oecologia, 151, 42-53.

310 Furuno, T. (1964) On the feeding quantity of the gypsy moth (Lymantria dispar Linne) and the camphor silk moth (Dictyoploca japonica Bulter). Journal of the Japanese Forest Society, 46, 14-19.

Giertych, M.J., Bakowski, M., Karolewski, P., \& Grzebyta, J. (2005) Influence of mineral fertilization on food quality of oak leaves and utilization efficiency of food components by the gypsy moth. Entomologia Experimentalis et Applicata, 117, 59-69.

Hättenschwiler, S., Tiunov, A.V., \& Scheu, S. (2005) Biodiversity and litter decomposition in terrestrial ecosystems. Annual Review of Ecology \& Systematics, 36, 191-218. 
Huberty, A.F. \& Denno, R.F. (2006) Consequences of nitrogen and phosphorus limitation for the performance of two planthoppers with divergent life-history strategies. Oecologia, 149, 444-455.

Hunter, M.D. (2001) Insect population dynamics meets ecosystem ecology: effects of herbivory on soil nutrient dynamics. Agricultural and Forest Entomology, 3, 77-84.

Huppe, H.C. \& Turpin, D.H. (1994) Integration of carbon and nitrogen metabolism in plant and algal cells. Annual Review of Plant Physiology and Plant Molecular Biology, 45, 577-607.

Hwang, S., Liu, C., \& Shen, T. (2008) Effects of plant nutrient availability and host plant species on the performance of two Pieris butterflies (Lepidoptera: Pieridae). Biochemical Systematics and Ecology, 36, 505-513.

Kuzhivelil, B.T. \& Mohamed, U.V.K. (1998) Allantoin and allantonic acid titre in the faeces and tissues of the developing larva of the moth, Orthaga exvinacea Hampson. Insect Biochemistry and Molecular Biology, 28, 979-986.

Lovett, G.M., Christenson, L.M., Groffman, P.M., Jones, C.G., Hart, J.E., \& Mitchell, M.J. (2002) Insect defoliation and nitrogen cycling in forests. BioScience, 52, 335-341. 
Lovett, G.M. \& Ruesink, A.E. (1995) Carbon and nitrogen mineralization from decomposing gypsy moth frass. Oecologia, 104, 133-138.

Madritch, M.D., Donaldson, J.R., \& Lindroth, R.L. (2007) Canopy herbivory can mediate the influence of plant genotype on soil processes through frass deposition. Soil Biology \& Biochemistry, 39, 1192-1201.

Martinoia, E., Heck, U., \& Wiemken, A. (1981) Vacuoles as storage compartments for nitrate in barley leaves. Nature, 289, 292-294.

O'Donnell, M. (2008) Insect excretory mechanisms. Advances in Insect Physiology, 35, 1-122.

Scriber, J.M. \& Slansky, F. (1981) The nutritional ecology of immature insects. Annual Review of Entomology, 26, 183-211.

Simpson, S.J. \& Raubenheimer, D. (2001) The geometric analysis of nutrient-allelochemical interactions: a case study using locusts. Ecology, 82, 422-439.

Slansky, F. \& Feeny, P. (1977) Stabilization of the rate of nitrogen accumulation by larvae of the cabbage butterfly on wild and cultivated food plants. Ecological Monographs, 47, 209-228.

Staley, J.T., Stewart-Jones, A., Poppy, G.M., Leather, S.R., \& Wright, D.J. (2009) Fertilizer 
affects the behaviour and performance of Plutella xylostella on brassicas. Agricultural

and Forest Entomology, 11, 275-282.

Sterner, R.W. \& Elser, J.J. (2002) Ecological Stoichiometry Princeton University Press,

Princeton.

Weisser, W.W. \& Siemann, E. (2004). The various effects of insects on ecosystem functioning.

Springer-Verlag, Berlin.

Wright, P.A. (1995) Nitrogen excretion: three end products, many physiological roles. The Journal of Experimental Biology, 198, 273-281.

Yorifuji, T., Niihata, M., Yamamura, K., Otsu, T., Iguchi, J., Hiramatsu, K., Suzuki, C., Ikemoto, T., Miyatake, M., \& Suzuki, T. (2005) Survey of nitrate concentrations in domestic vegetables on the market. Nippon Shokuhin Kagaku Kogaku Kaishi, 52, 605-609. 


\section{Figure Legends}

Fig. 1: (a) total $\mathrm{N}$ concentration, (b) $\mathrm{NO}_{3}{ }^{-}-\mathrm{N}$ concentration , and (c) $\mathrm{NH}_{4}{ }^{+}-\mathrm{N}$

concentration of the $B$. rapa leaves at different fertilization levels. Means \pm SE are presented. Different letters indicate a significant difference $(\mathrm{P}<0.05)$.

Fig. 2: (a) Mass consumption, (b) frass mass excreted by M. brassicae during the $48 \mathrm{~h}$ feeding trials. Means \pm SE are presented. ns indicates no significant difference (P $>0.05$ ). (c) efficiency of frass excretion. Efficiency of frass excretion was shown by the relationship between ingested and excreted mass. Each point represents the treatment average with SE. Dotted line shows $\mathrm{Y}=\mathrm{X}$. Area above the line represents that excreted mass is more than ingested mass, and vice versa.

Fig. 3: (a) total $\mathrm{N}$ concentration, (b) $\mathrm{NO}_{3}{ }^{-}-\mathrm{N}$ concentration , and (c) $\mathrm{NH}_{4}{ }^{+}-\mathrm{N}$ concentration in the frass of $M$. brassicae. Means \pm SE are presented. Different letters indicate a significant difference $(\mathrm{P}<0.05)$.

Fig. 4: (a) efficiency of total $\mathrm{N}$ excretion, (b) efficiency of $\mathrm{NO}_{3}{ }^{-}-\mathrm{N}$ excretion, and (c) efficiency of $\mathrm{NH}_{4}{ }^{+}-\mathrm{N}$ excretion, and (d) relationship between ingested $\mathrm{N}$ and 
excreted $\mathrm{NH}_{4}{ }^{+}-\mathrm{N}$. Efficiency of excretion was shown by the relationship between ingested and excreted mass. Each point represents the treatment average with SE.

Dotted line shows $\mathrm{Y}=\mathrm{X}$. Area above the line represents that excreted mass is more than ingested mass, and vice versa. 
Fig. 1

(a)

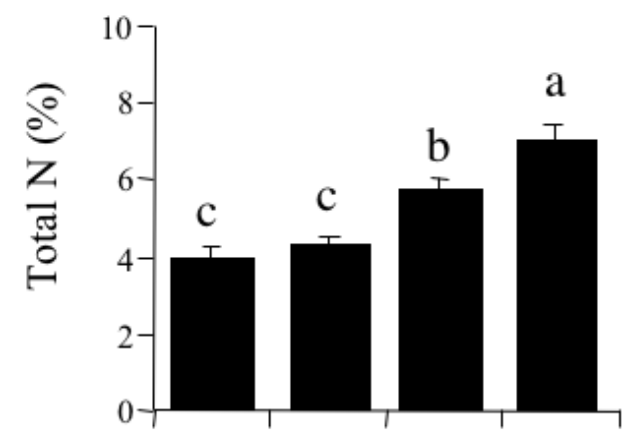

(b)

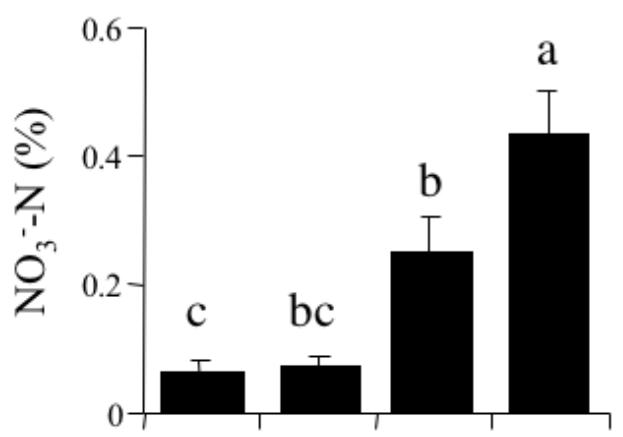

(c)

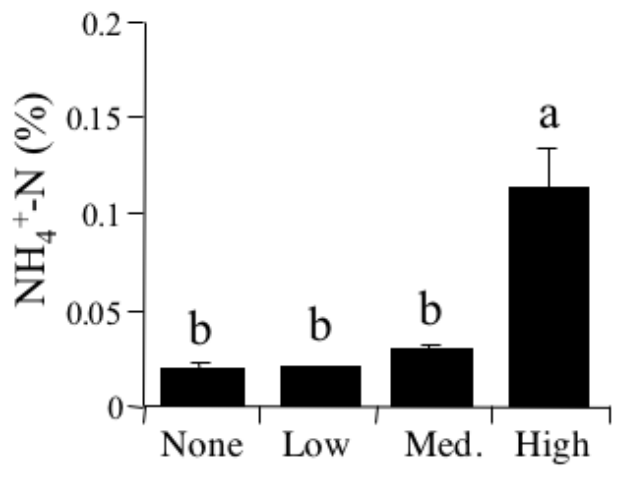

Level of fertilization 
Fig. 2

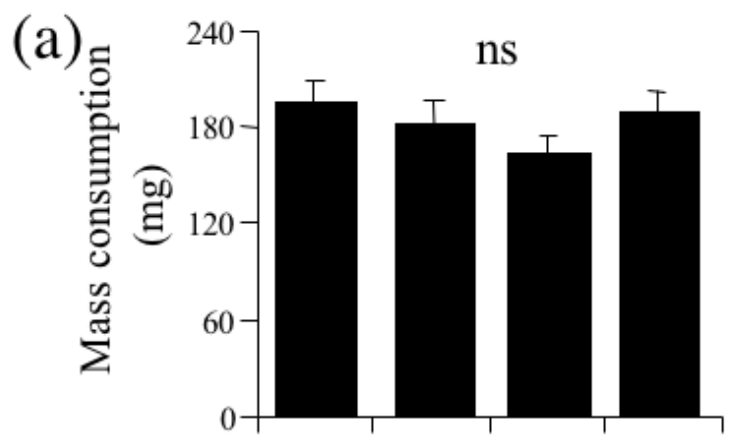

(b)

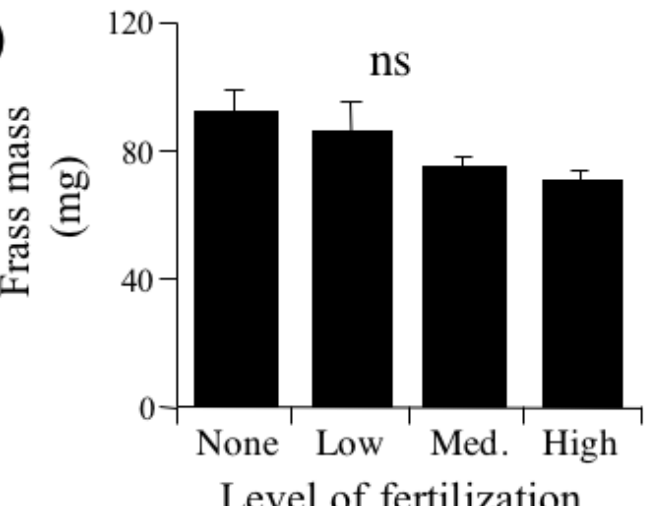

(c)

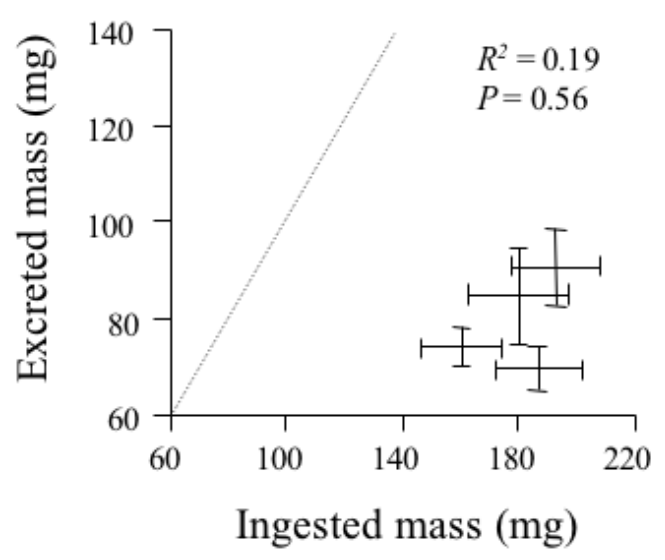


$390 \quad$ Fig. 3

(a)

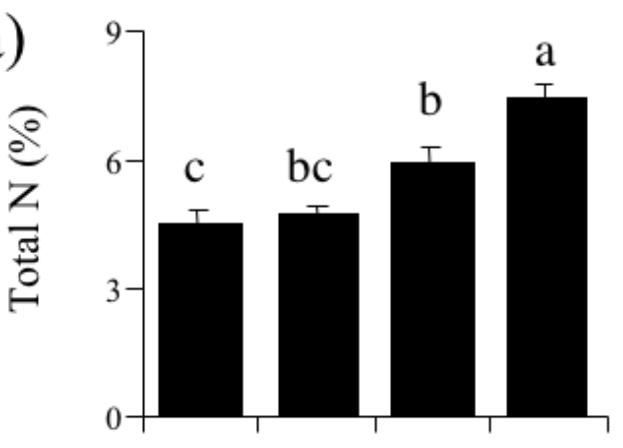

(b)

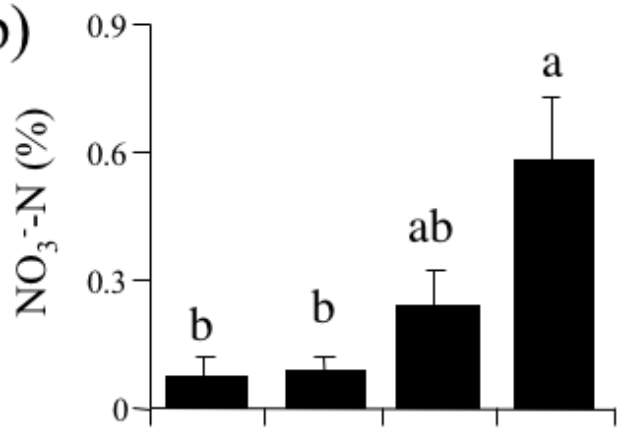

(c)

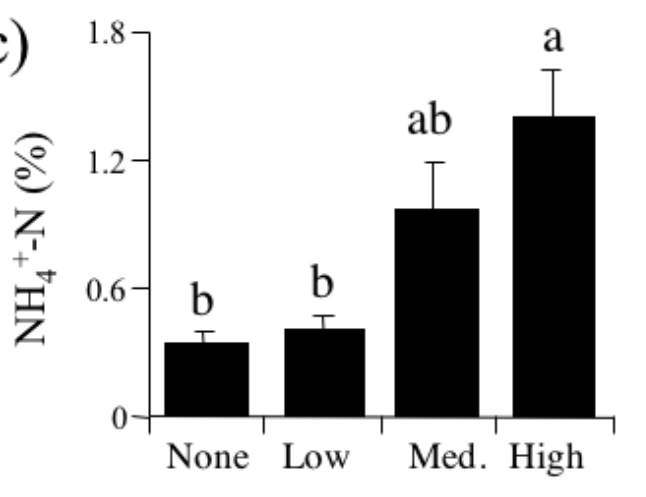

Level of fertilization 
Fig. 4
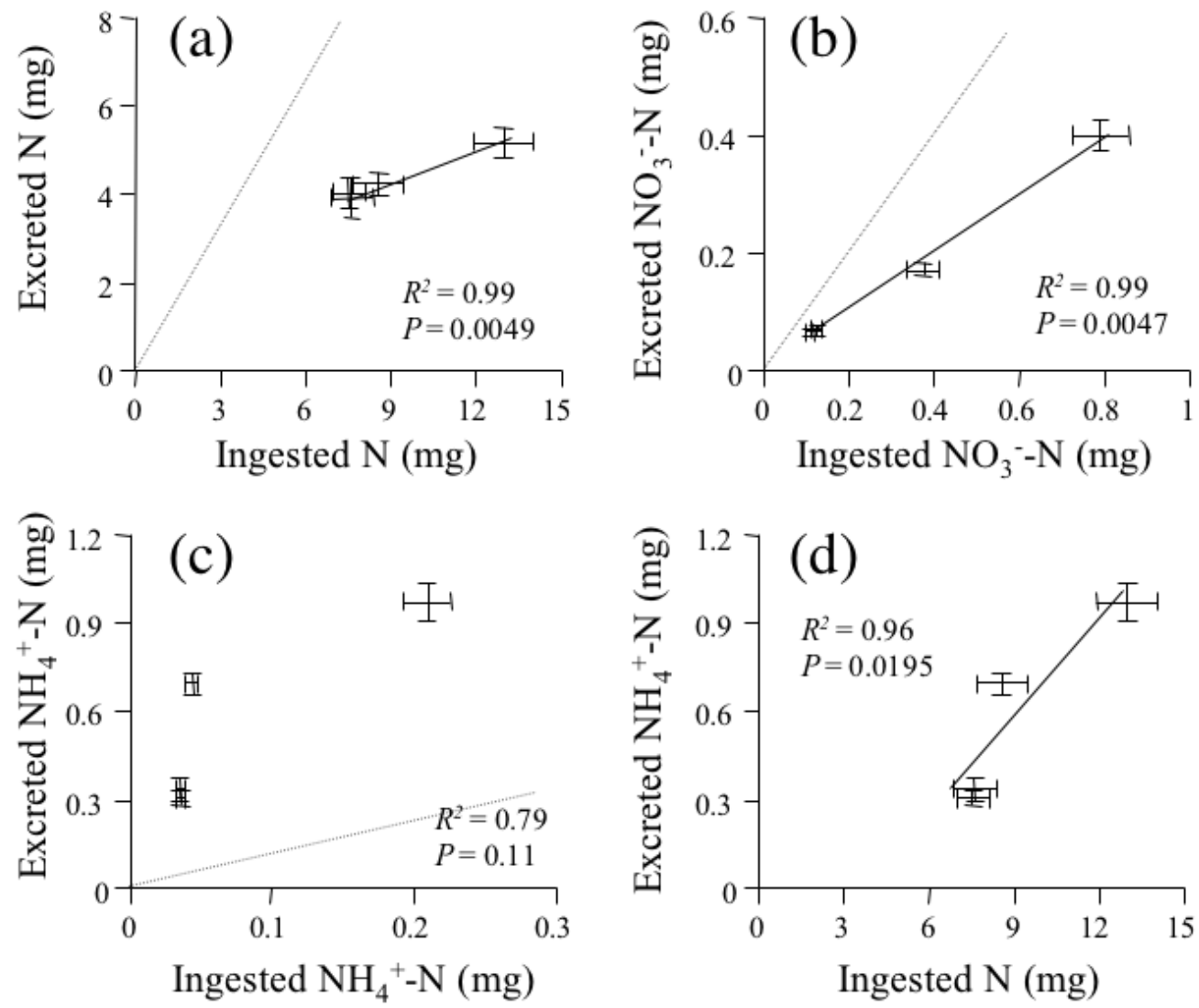